\title{
PENGEMBANAN FILSAFAT PANCASILA DALAM SISTEM PEMIDANAAN DI INDONESIA
}

\author{
Ali Dahwir \\ Fakultas Hukum Universitas Palembang \\ e-mail:dahwirali@yahoo.com
}

\begin{abstract}
In general, the system of imposing crimes against perpetrators of criminal acts applied in Indonesia still refers to the criminal system which was abandoned by the Dutch Colonial based on liberalism, this is due to the absence of regulations made by Indonesia that specifically establish the criminal system. So that the criminal system that runs is not based on the local wisdom of the Indonesian people which ultimately does not reflect the values of Pancasia as a source of all legal sources. The purpose of this paper is to examine the development of the philosophy of Pancasila in the penal system. This research is normative, using secondary data, with a legal philosophy and concept approach. Qualitatively analyzed to find links between criminal prosecution in Indonesia and the adoption of Pancasila values
\end{abstract}

Keywords: Philosophy; Pancasila; Criminal System

\begin{abstract}
Abstrak
Secara umum sistem penjatuhan pidana terhadap pelaku tindak pidana yang diterapkan di Indonesia masih mengacu kepada sistem pemidanaan yang di tinggalkan oleh Kolonial Belanda yang berlandaskan liberalisme, hal ini disebabkan oleh belum ada aturan yang dibuat oleh Indonesia yang secara khusus menetapkan sistem pemidanaan. Sehingga sistem pemidanaan yang berjalan tidak berdasarkan kearifan lokal masyarakat Indonesia yang pada akhirnya tidak mencerminkan nilai-nilai Pancasia sebagai sumber dari segala sumber hukum. Tujuan penulisan ini adalah untuk mengkaji tentang pengembanan filsafat Pancasila dalam sistem pemidanaan. Penelitian ini bersifat normatif, dengan menggunakan data-data sekunder, dengan pendekatan konsep dan filsafat hukum. Dianalisis secara kualitatif untuk menemukan keterkaitan antara penjatuhan pidana di Indonesia dengan pengembanan nilai-nilai Pancasila
\end{abstract}

Kata Kunci: Filsafat, Pancasila, Sistem Pemidanaan

\section{A. Pendahuluan}

Negara merupakan organisasi manusia yang paling besar dimana masyarakat menundukkan diri. Negara adalah lembaga yang memiliki kekuasaan yang sangat besar didalam sebuah masyarakat, kekuasaan yang sangat besar ini diperoleh karena negara merupakan pelembagaan dari kepentingan umum. Pada hakekatnya negara adalah suatu organisasi masyarakat, yaitu sekelompok orang dengan kerja sama dan pembagian tugas, mengejar suatu tujuan yang bersama yang tidak dapat dicapai secara sendiri-sendiri.
Dalam suatu negara yang menjadi petugas atau aparaturnya adalah mereka yang menjadi pucuk pimpinan dari organisasi itu, merekalah yang bertugas menjaga dan mengatur agar tujuan organisasi tersebut dapat terwujud. Dalam suatu negara dibentuk alat-alat perlengkapan negara atau lembaga-lembaga tinggi negara. ${ }^{1}$

Kekuasaan negara harus pula dibatasi agar tidak berlaku sewenangwenang terhadap warganya. Adapun yang

1 Kirdi Dipoyudo, Keadilan Sosial. Seri Penghayatan dan Pengamalan Pancasila, Rajawali, Jakarta, 1985, hal. 1-2 
dapat membatasi kekuasaan negara adalah hukum. Inilah yang disebut dengan negara hukum. Negara hukum dalam sejarahnya berjalan sesuai dengan perkembangan masyarakat. $^{2}$

Menurut Stahl, suatu negara hukum haruslah memenuhi empat unsur penting, yakni: ${ }^{3}$

a. Adanya jaminan atas hak-hak dasar manusia;

b. Adanya pembagian kekuasaan;

c. Pemerintahan haruslah berdasarkan atas peraturanperaturan hukum;

d. Adanya peradilan administrasi.

Negara hukum bertujuan untuk menjamin adanya kepastian hukum dalam masyarakat. Hukum bertujuan untuk mewujudkan kepastian dalam hubungan antar manusia, yakni menjamin prediktabilitas, dan juga bertujuan untuk mencegah bahwa hak yang terkuat yang berlaku. ${ }^{4}$

Indonesia adalah negara hukum, hal tersebut secara tegas tertera dalam Pasal. 1 ayat (3) Undang-undang Dasar 1945, yang idealnya segala tindak tanduk pemerintah haruslah didasarkan pada aturan hukum yang ada, aturan hukum tersebut juga tidak boleh menyimpangi Pancasila sebagai Ideologi Bangsa. Sebagai ideologi bangsa Indonesia dalam menjalankan negara hukum yang dimaksud pemerintahan tidak boleh terlepas dari Pancasila yang juga merupakan sumber dari segala sumber hukum di Indonesia.

Demikian juga halnya ketika terjadi tindak pidana atau kekacauan dalam

\footnotetext{
${ }^{2}$ Ibid.

3 Stahl, dalam Abu Daud Busroh dan Abubakar Busro, Asas-Asas Hukum Tata Negara, Ghalia Indonesia, Jakarta, 1982, hal.112-113

4 Untuk mewujudkan tujuan, negara tersebut harus memnuhi unsur petugas, kewenangan (tugas), menurut teori yang dikemukakan oleh Montesquieu (trias Politica) agar suatu pemerintahan berjalan dengan baik harus melakukan pemisahan kekuasaan, dan masingmasing kekuasaan harus mengawasi kekuasaan yang lainnya sehingga tiap kekuasaan tersebut menjadi balance.
}

masyarakat yang dilakukan oleh seseorang, akan mengakibatkan hilangnya keseimbangan dalam masyarakat yang bersangkutan, serta menimbulkan penderitaan pada korbannya. Sebagai pelaku kejahatan sudah semestinya mendapatkan sanksi sesuai dengan keadilan masyarakat, serta tidak mengenyampingkan keberadaan Pancasila.

Immanuel Kant berpendapat bahwa dasar penjatuhan hukuman haruslah dicari pada kejahatan itu sendiri, sebab kejahatan itu menimbulkan penderitaan pada orang lain sementara hukuman tersebut merupakan tuntutan yang mutlak dari hukum kesusilaan. ${ }^{5}$ Teori ini lebih terkenal dengan teori absolut dalam pemidanaan, sedangkan menurut teori relatif menganggap bahwa orang yang melakukan kejahatan merupakan orang yang tersesat dalam pergaulan masyarakat, sehingga mereka perlu dibimbing yang pada akhirnya apabila telah kembali pada masyarakat mereka menjadi orang yang berguna ${ }^{6}$ dan teori gabungan merupakan teori yang dalam menjatuhkan pidana kepada pelaku pidana menggabungkan antara teori absolut dengan teori relatif.

Dalam penjatuhan pidana di Indonesia, yang secara jelas terlihat masih berdasarkan pada ketentuan yang dibuat oleh pemerintah Kolonial Belanda, hal tersebut tidak dapat dipungkiri, karena ini merupakan konsekuensi dari Pasal II Aturan Peralihan UUD1945 yang menyatakan bahwa " segala badan negara dan peraturan yang ada masih langsung berlaku, selama belum diadakan yang baru menurut Undang-undang ini'”. Penjatuhan pidana dalam hal ini merupakan bahagian dari penegakan hukum.

Penegakan hukum haruslah disesuaikan dengan cita-cita hukum bangsa yang bersangkutan (Proklamasi, Pancasila, dan UUD 1945). Artinya, penegakan hukum tersebut haruslah disesuaikan

5 Satochit Kartanegara, Hukum Pidana (Kumpulan Kuliah Bagian I), Balai Lektur Mahasiswa, Tanpa Tahun, hal. 57

${ }^{6}$ Ibid., hal. 62 
dengan falsafah, pandangan hidup, kaidah dan prinsip yang di anut oleh masyarakat yang bersangkutan, shingga akan sesuai dengan kesadaran hukum yang mereka miliki. Untuk itu penegakan hukum haruslah disesuaikan dengan nilai-nilai yang di junjung tinggi oleh masyarakat, yang bagi masyarakat Indonesia nilai-nilai tersebut , antara lain nilai ketuhanan, keadilan, kebersamaan, kedamaian, ketertiban, kemodernan musyawarah, perlindungan hak-hak asasi dan sebgainya. Tentunya sebagai negara yang menganut sistem hukum eropa kontinental, sedapat mungkin nilai-nilai tersebut dinyatakan dalam bentuk undang-undang termasuk dalam hal nilai dan kaidah penegakan hukumnya. jadi nilai-nilai luhur dari pancasila seperti keadilan, kemanusiaan dan hak asasi manusia (martabat manusia), kepastian hukum, kemanfaatan dan persatuan bangsa harus diinternalisasi dalam dinamika praktik penegakan hukum.

Dalam konteks sistem peradilan pidana, maka ruang lingkup penegakan hukum pidana sudah dimulai sejak perumusan peraturan perundang-undangan oleh lembaga legislatif (kebijakan legislatif) di bidang hukum pidana baik hukum pidana materil maupun formil, pelaksanaan perundang-undangan itu di masyarakat, maupun langkah atau tindakan yang diambil atau seharusnya diambil oleh aparat penegak hukum pidana seperti polisi, jaksa penununtut umum, hakim, dan penasehat hukum manakala di masyarakat terjadi tindak pidana atau pelanggaran terhadap hukum pidana yang ada harus tetap memperhatikan dan sesuai dengan nilai-nilai luhur Pancasila. Penyelenggaraan acara pidana (khususnya untuk tindak pidana umum) di dasarkan pada undang-undang Nomor.8 tahun 1981 tentang Hukum Acara Pidana, yang populer dengan sebutan KUHAP, UU kekuasaan kehakiman, dan peraturan perundangundangan lainnya sebgai pelengkap. KUHAP dan UU kekuasaan kehakiman itu memuat asas-asas yang harus diwujudkan dalam penyelenggaraan acara pidana, khususnya oleh jajaran aparat penegak hukum (official criinal justice system).

\section{B. Permasalahan}

Dari uraian singkat di atas banyak terdapat permasalahan dalam pemidanaan di Indonesia, permasalahan dalam hal penjatuhan pidana, pemidanaan, landasan penjatuhan pidana, dan lain sebagainya. Untuk itu penulis merumuskan permasalahan dalam makalah ini sebagai berikut:

1. Bagaimana penjatuhan pidana di Indonesia dalam konstelasinya dengan nilai-nilai Pancasila?

2. Bagaimana idealnya penjatuhan pidana dalam sistem pemidanaan di Indonesia?

\section{Pembahasan}

Kejahatan merupakan kenyataan sosial, yang sudah ada sejak terciptanya manusia di muka bumi ini. Dalam hukum pidana kejahatan lebih fokus disebut sebagai tindak pidana, karena suatu perbuatan disebut sebagai tindak pidana apabila memenuhi perumusan dalam asas legalitas. ${ }^{7}$ Memahami makna asas legalitas, tergambar sebuah supremasi hukum bagi masyarakat yang hidup dalam sebuah negara, karena dengan adanya asas ini pemerintah tidak dapat melakukan kesewenang-wenangan terhadap rakyat. Seperti yang pernah terjadi pada masamasa sebelum revolusi Perancis. Seiring dengan perkembangan zaman, bentuk kejahatanpun berkembang dan semakin bervariasi jenis operandinya serta korbanya bukan lagi berbentuk individu bahkan sudah merupakan korban yang kolektif dan sistematis.

Dalam peraturan perundangundangan Indonesia tidak ditemukan definisi tindak pidana. Pengertian tindak

7 Tiada suatu perbuatan boleh dihukum, melainkan atas kekuatan ketentuan pidana dalam undang-undang, yang ada terlebih dahulu daripada perbuatan itu. R. Soesilo, Kitab Undang-undang Hukum Pidana (KUHP) Serta Komentarkomentarnya Lengkap Pasal Demi Pasal, Politeia, Bogor, 1996, hal. 27 
pidana yang dipahami selama ini merupakan kreasi teoretis para ahli hukum. Para ahli hukum pidana pada umumnya masih memasukkan kesalahan sebagai bagian dari pengertian tindak pidana. ${ }^{8}$

Mengenai pengertian strafbaarfeit antara para sarjana tidak ada kesatuan pendapat, mereka menyebut strafbaarfeit itu dengan istilah mereka masing-masing antara lain Moeljatno, mengartikan srafbaarfeit sebagai perbuatan pidana, dengan perumusan : "suatu perbuatan yang dilarang oleh suatu aturan hukum larangan mana disertai ancaman (sanksi) yang berupa pidana tertentu, bagi siapa yang melanggar larangan tersebut". 9 Simon mengatakan bahwa strafbaarfeit itu adalah kelakuan yang diancam dengan pidana, bersifat melawan hukum, dan berhubung dengan kesalahan yang dilakukan oleh orang yang mampu bertanggungjawab. ${ }^{10}$

Strafbaarfeit atau delict dalam bahasa Indonesia banyak diterjemahkan seperti: Tindak Pidana, perbuatan pidana, Pelanggaran Pidana, Perbuatan yang boleh dihukum dan perbuatan yang dapat dihukum. ${ }^{11}$ Berdasarkan uraian di atas dapat disimpulkan bahwa yang dimaksud dengan tindak pidana ialah : suatu perbuatan atau rangkaian perbuatan manusia yang bertentangan dengan Undang-undang atau peraturan lainnya, terhadap perbuatan itu dapat diancam dengan pidana. Perbuatan itu merupakan tindak pidana apabila memenuhi syaratsyarat yang dimuat di dalam dalil yang bersangkutan.

Orang yang melakukan tindak

${ }^{8}$ Chairul Huda, Dari Tindak Pidana Tanpa
Kesalahan Menuju Kepadar Tiada
Pertanggungjawaban Pidana Tanpa Kesalahan:
Tinjauan Kritis terhadap teori Pemisahan Tindak
Pidana dan Pertanggungjawaban Pidana, Kencana
Prenada Media, Jakarta, 2006, hal. 26
${ }^{9}$ Moeljatno, Azas-azas Hukum Pidana,
Bina Aksara, Jakarta,1985, hal. 54
${ }^{10}$ S.R. Sianturi, Asas-asas Hukum Pidana
di Indonesia dan Penerapannya, Alumni AHAEM-
PTHAEM, Jakarta, 1986, hal. 205
Mustafa Abdullah dan Ruben Achmad,
Intisari Hukum Pidana, Ghalia Indonesia, Jakarta,
1986, hal. 25-27

pidana sudah semestinya mendapatkan hukuman, sesuai dengan ketentuan peraturan perundang-undangan. Penjatuhan pidana terhadap pelaku tindak pidana urgen dilakukan meskipun pelakunya orang yang memiliki strata sosial tertentu, hal ini untuk menciptakan supremasi hukum, semua orang bersamaan kedudukannya di depan hukum.

\section{Penjatuhan Pidana di Indonesia Dalam Konstelasinya Dengan Nilai- Nilai Pancasila}

Perjalanan sejarah bangasa Indonesia dari kolonial ke kemerdekaan adalah suatu perjalanan paradigmatis. Secara politik berubah dari bangsa pinggiran (periferi) menjadi bangsa yang mengambil alih pusat kekuasaan melalui proklamasi kemerdekaan pada Agustus 1945: dari Hindia Belanda menjadi Republik Indonesia. Tidak semua bangsa dalam kemerdekaannya ingin membangun suatu kehidupan baru yang didasarkan pada asas-asas baru. Disini peranan UUD 1945 sangat menentukan terjadinya perubahan yang melompat itu. UUD merupakan grand desaign suatu masyarakat dan kehidupan baru di Indonesia. ${ }^{12}$

Dengan demikian, UUD 1945 merupakan instrumen yang sangat penting dalam proses membangun masyarakat baru Indonesia dan menjadi modal bagi pembangunan hukum di Indonesia. Oleh karena itu. Ilmu Hukum Indonesia yang bertugas mendeskripsikan dan menjelaskan kehidupan hukum di negeri ini juga tak dapat dipisahkan dari UUD 1945. Menunujuk pada pemikiran tersebut, paradigma yang dapat ditangkap dari UUD 1945 antara lain : (a) Ketuhanan Yang Maha Esa;(b) Kemanusiaan;(c) Persatuan; (d) kerakyatan; (e) keadilan sosial; (f) kekeluargaan; (g) harmoni; musyawarah.

Paradigma di atas dapat menuntun dalam bidang penyelenggraan suatu negara hukum, yakni pembuatan UU, penegakan hukum dan peradilan. Tatanan hukum yang

\footnotetext{
${ }^{12}$ Sajipto Raharjo, Paradigma Ilmu Hukum, Alumni, Bandung, 1989, hal. 34
} 
beroperasi dalam suatu masyarakat pada dasarnya merupakan pengejawantahan cita hukum yang dianut dalam masyarakat yang bersangkutan ke dalam berbagai perangkat aturan positif, lembaga hukum dan proses (perilaku birokrsi pemerintahan dan masyarakat). ${ }^{13}$ Pembangunan dan pembinaan hukum di Indonesia didasarkan atas pancasila dan UUD 1945. Secara implisit memperlihatkan, bahwa penyusunan hukum yang berlaku di Indonesia tak dapat di lepaskan dengan pandangan hidup bangsa, Pancasila. Dengan Pancasila sebagai pandangan hidup, maka paham negara hukum tidak seperti dianut dalam budaya hukum barat. Demikin halnya dalam penjatuhan pidana haruslah disesuaikan dengan kearifan lokal, yakni berdsasarkan pada hukum yang tumbuh dan berkembang dalam masyarakat Indonesia.

Negara dalam menjatuhkan pidana haruslah menjamin kemerdekaan individu dan menjaga supaya pribadi manusia tetap dihormati. ${ }^{14}$ Oleh karena itu pemidanaan harus mempunyai tujuan dan fungsi yang dapat menjaga keseimbangan individu dengan kepentingan masyarakat untuk mencapai kesejahteraan bersama. Falsafah seperti ini akan sejalan dengan filsafat Pancasila, terutama pada sila kelima "keadilan sosial bagi seluruh rakyat Indonesia" hal ini sesuai dengan apa yang dikatakan oleh Barda Nawawi Arief: bahwa tujuan dari kebijakan pemidanaan yaitu menetapkan suatu pidana tidak terlepas dari tujuan politik kriminal. Dalam arti keseluruhannya yaitu perlindungan masyarakat untuk mencapai kesejahteraan.

Oleh karena itu untuk menjawab dan mengetahui tujuan serta fungsi pemidanaan, maka tidak terlepas dari teori-

${ }^{13}$ Bernard Arief Sidharta, Paradigma Ilmu Hukum Indonesia Dalam Perspektif Positivis, Universitas Diponegoro, Semarang, 1998, hal.27

${ }^{14}$ Sesuai dengan sila kedua Pancasila yaitu kemanusiaan yang adil dan beradab, artinya penjatuhan pidana tetap dalam koridor perlindungan HAM dengan tidak mengenyampingkan keadilan korban dan masyarakat. teori tentang pemidanaan yang ada. ${ }^{15}$ Menurut Satochid Kartanegara dan pendapat-pendapat para ahli hukum terkemuka dalam hukum pidana, mengemukakan teori pemidanaan atau penghukuman dalam hukum pidana dikenal ada tiga aliran yaitu:

a. Absolute atau vergeldings theorieen (vergelden/imbalan)

Aliran ini mengajarkan dasar dari pemidanaan harus dicari pada kejahatan itu sendiri untuk menunjukkan kejahatan itu sebagai dasar hubungan yang dianggap sebagai pembalasan, imbalan (velgelding) terhadap orang yang melakukan perbuatan jahat. Oleh karena kejahatan itu menimbulkan penderitaan bagi si korban. Teori ini melihat bahwa sipelaku kejahatan urgen harus dihukum dan orientasi pemidanaan ini adalah negara dan koraban dari kejahatan.

b. Relative atau doel theorieen (doel/maksud, tujuan)

Dalam ajaran ini yang dianggap sebagai dasar hukum dari pemidanaan adalah bukan velgelding, akan tetapi tujuan (doel) dari pidana itu. Jadi aliran ini menyandarkan hukuman pada maksud dan tujuan pemidanaan itu, artinya teori ini mencari mamfaat daripada pemidanaan (nut van de straf). ${ }^{16}$ Sehingga dapat diartikan bahwa orientasi pemidanaan dalam teori ini adalah pelaku kejahatan, yang seolaholah tidak melihat akibat yang ditimbulkan oleh kejahatan tersebut.

c. Vereningings theorieen (teori gabungan)

Teori ini memberikan statement bahwa penjatuhan pidana semata-mata karena seseorang telah melakukan suatu kejahatan atau tindak pidana. Pidana merupakan akibat mutlak yang harus ada sebagai suatu pembalasan kepada orang yang telah melakukan kejahatan.

${ }^{15}$ Muladi dan Barda Nawawi Arief, TeoriTeori dan Kebijakan Pidana, Alumni, Bandung, 2005, hal. 149

${ }^{16}$ Satochid Kartanegara, Op. cit, hal. 56 
Adapun yang menjadi dasar pembenarannya dari penjatuhan pidana itu terletak pada adanya kejahatan itu sendiri, oleh karena itu pidana mempunyai fungsi untuk menghilangkan kejahatan tersebut. Johanes Andenaes, mengatakan bahwa tujuan utama dari pidana adalah untuk memuaskan tuntutan keadilan (to satesfy the claims of justice), sedangkan pengaruh-pengaruh lainnya yang menguntungkan adalah hal sekunder jadi menurutnya bahwa pidana yang dijatuhkan semata-mata untuk mencari keadilan dengan melakukan pembalasan. ${ }^{17}$

M. Sholehuddin menyatakan, bahwa masalah sanksi merupakan hal yang sentral dalam hukum pidana karena seringkali menggambarkan nilai-nilai sosial budaya suatu bangsa. Artinya pidana mangandung tata nilai (value) dalam suatu masyarakat mengenai apa yang baik dan yang tidak baik, apa yang bermoral dan apa yang amoral serta apa yang diperbolehkan dan apa yang dilarang. ${ }^{18}$ Namun dalam kenyataannnya sanksi pidana yang diancamkan dalam ketentuan KUHP tidaklah berdasarkan jiwa bangsa Indonesia, disatu sisi dan disisi yang lain para aparan penegak hukum harus tunduk pada ketentuan peraturan Perundangundangan yang ada (asas legalitas).

Sistem merupakan jalinan dari beberapa unsur yang menjadi satu fungsi. Sistem pemidanaan memegang posisi strategis dalam upaya untuk menanggulangi tindak pidana yang terjadi. Sistem pemidanaan adalah suatu aturan perundang-undangan yang berhubungan dengan sanksi pidana dan pemidanaan. Apabila pengertian sistem pemidanaan diartikan secara luas sebagai suatu proses pemberian atau penjatuhan pidana oleh hakim, maka dapatlah dikatakan bahwa

\footnotetext{
${ }^{17}$ Muladi, Op cit, hal. 11

${ }^{18}$ Ekaputra, Mohammad dan Abul Khair,

Sistem Pidana Di Dalam KUHP Dan Pengaturannya Menurut Konsep KUHP Baru, USU Press, Medan, 2010, hal. 13
}

sistem pemidanaan mencakup keseluruhan ketentuan perundang-undangan yang mengatur bagaimana hukum pidana itu ditegakkan atau dioperasionalkan secara konkret sehingga seseorang dijatuhi sanksi (hukum) pidana. Ini berarti semua aturan perundang-undangan mengenai hukum pidana subtantif, hukum pidana formal dan hukum pelaksanaan pidana dapat dilihat sebagai satu kesatuan sistem pemidanaan. Dengan demikian dapatlah dikatakan bahwa pemidanaan tidak dapat terlepas dari jenis-jenis pidana yang diatur dalam hukum positif suatu negara.

Pemidanaan yang dilakukan oleh suatu masyarakat yang teratur terhadap pelaku kejahatan dapat berbentuk menyingkirkan atau melumpuhkan para pelaku tindak pidana, sehingga pelaku tersebut tidak lagi menggangu di masa yang akan datang. Cara menyingkirkan dapat dilakukan bermacam-macam yaitu berupa pidana mati, pembuangan, pengiriman keseberang lautan dan sampai pemenjaraan. Secara berangsur-angsur ada kecenderungan cara pemidanaan itu mengalami pergeseran dari waktu ke waktu.

Pada zaman kerajaan majapahit dikenal sistem pemidanaan berupa; pidana pokok yang meliputi pidana mati, pidana potong anggota badan bagi yang bersalah, denda, ganti kerugian, atau pangligawa atau putukucawa. Selain itu dikenal juga pidana tambahan yang meliputi tebusan, penyitaan dan patibajambi (uang pembeli obat). Dalam kitab perundang-undangan Majapahit sama sekali tidak mengenal pidana penjara dan pidana kurungan. Dengan demikian setiap orang yang bersalah harus menjalani salah satu dari empat pidana pokok di atas. ${ }^{19}$ Pada masa ini sudah jelas kelihatan bahwa pemidanaan itu berorintasi pada korban, dimana korban diharapkan mendapatkan rasa keadilan dengan pidana yang dijatuhkan, namun demikian terlihat bahwa

19 Andi Hamzah dan Siti Rahayu, Suatu Tinjauan Ringkas Sistem Pemidanaan Di Indonesia, Akademik Pressindo, Jakarta, 1986, hal. 4 
apa yang terkandung dalam sila kedua Pancasila tidak terpenuhi yaitu"kemanusiaan yang adil dan beradab". Sebab pemidanaan seolah-olah terjadi pada masyarakat yang barbar, tanpa perlindungan HAM.

Seperti pidana pokok yang ditentukan adanya pidana potong anggota badan yang bersalah, ini menunjukkan kurangnya landasan pada perlindungan Hak Asasi manusia. Sehingga pidana seperti ini juga kurang relevan dijalankan bagi negara Indonesia yang notabennya merupakan negara hukum.

Berbeda dengan keadaan Majapahit, untuk keadaan sekarang sistem pemidanaan telah mengalami banyak perubahanperubahan yang berupa penyempurnaan dari sistem yang telah lalu. Tidak telepas pula dengan keadaan di Indonesia, sistem pemidanaan yang ada dan berlaku hingga sekarang masih mengacu pada KUHP yang merupakan warisan Kolonial Belanda. Dari sistem ini yang tercantum dalam KUHP tersebut banyak menimbulkan permasalahan, diantaranya tentang relevansi sistem pemidanaan yang dipakai dewasa ini dengan keadaan dan aspirasi bangsa Indonesia.

Dari uraian pemidanaan yang telah disampaikan di atas terlihat jelas telah terjadi kesalahan yang mendasar bagi hukum Indonesia. Dimana pemidanaan yang telah ditentukan tidaklah berdasarkan pada kearifan masyarakat Indonesia, hal ini sangat mungkin terjadi karena landasan pembentukan KUHP (Wet Book van Strafrecht) tersebut tidaklah berdasarkan jiwa bangsa Indonesia, tidaklah dijiwai oleh ideologi Pancasila, akan tetapi dijiwai oleh bangsa Kolonial Belanda.

\section{Penjatuhan Pidana Dalam Sistem Pemidanaan di Indonesia Dimasa Yang Akan Datang}

Keberadaan Pancasila sebagai falsafah kenegaraan atau staatsidee (cita negara) yang berfungsi sebagai filosofiche grondslag dan common platforms atau kalimatun sawa diantara sesama warga masyarakat dalam konteks kehidupan bernegara dalam kesepakatan pertama penyelenggara konstitusionalisme menunjukkan hakikat Pancasila sebagai ideologi terbuka. ${ }^{20}$ Konsekuensi Pancasila sebagai ideologi terbuka adalah membuka ruang membentuk kesepakatan masyarakat bagaimana mencapai cita-cita dan nilai dasar tersebut.

Aplikasi dari ideologi pancasila sebagai landasan pemidanaan sudah tergambar dalam rancangan KUHP 2008. Sistem pemidanaan yang digunakan dalam konsep atau rancangan ini terdiri dari dua jenis yaitu jenis pidana dan tindakan yang nampak telah digali dari nilai-nilai kemasyarakatan Indonesia dengan tidak mengenyampingkan keberadaan korban yang mengalami penderitaan.

Sistem pemidanaan dari sudut fungsional/luas, merupakan keseluruhan sistem (aturan perundang-undangan) mengenai bagaimana hukum pidana itu ditegakkan atau dioperasionalkan secara konkret sehingga seseorang dijatuhi sanksi (hukum) pidana. Dengan pengertian demikian, sistem pemidanaan identik dengan sistem penegakan hukum pidana yang terdiri dari sub-sistem Hukum Pidana Materiil / Substantif, sub-sistem Hukum Pidana Formil dan sub sistem Hukum Pelaksana Pidana. Sistem pemidanaan dari sudut substantif/sempit merupakan keseluruhan aturan perundang-undangan yang berkaitan dengan pidana dan pemidanaan.

Kebijakan sistem pemidanaan merupakan bagian dari kebijakan hukum pidana oleh karenanya juga merupakan usaha mewujudkan perundang-undangan pidana yang sesuai dengan keadaan dan situasi pada suatu waktu dan untuk masamasa yang akan datang. Dengan demikian kebijakan sistem pemidanaan juga merupakan bagian dari pembaharuan hukum Pidana.

${ }^{20}$ Teguh Prasetyo, Filsafat, Teori \& Ilmu Hukum (Pemikiran menuju Masyarakat yang berkeadilan dan Bermartabat), PT. Raja Grafindo persada, Jakarta, 2012, hal. 367 
Barda Nawawi Arief menegaskan, bahwa ketiga sub-sistem itu merupakan satu kesatuan sistem penegakan hukum pidana atau sistem pemidanaan, karena tidak mungkin hukum pidana dioperasionalisasikan/ ditegakkan secara konkret hanya dengan salah satu subsistem. Dengan demikian pembaharuan sub-sistem Hukum Pidana Materiil diikuti pula oleh pembaharuan sub-sistem Hukum Pidana Formil dan sub-sistem Hukum Pelaksanaan Pidana. Upaya operasionalisasi sistem penegakan hukum pidana/sistem pemidanaan dilakukan melalui rangkaian tahapan kebijakan, yaitu tahap kebijakan legislatif/formulatif, tahap kebijakan yudikatif/aplikatif dan tahap kebijakan eksekutif/administratif.

Kalau pada tahap kebijakan legislatif/formulatif ditetapkan sistem pemidanaan, maka pada hakikatnya sistem pemidanaan itu merupakan sistem kewenangan/kekuasaan menjatuhkan pidana. Pengertian pidana tidak hanya dapat dilihat dalam arti sempit/formal, tetapi juga dapat dilihat dalam arti luas/materiil. Dalam arti sempit/formal, penjatuhan pidana berarti kewenangan menjatuhkan/ mengenakan sanksi pidana menurut undang-undang oleh pejabat yang berwenang (hakim). Dalam arti luas/materiil, penjatuhan pidana merupakan suatu mata rantai proses tindakan hukum dari pejabat yang berwenang, melalui proses penyidikan, penuntutan, sampai pada putusan pidana dijatuhkan oleh pengadilan dan dilaksanakan oleh aparat pelaksana pidana.

Pembaharuan keseluruhan sistem hukum pidana materiil yang terdapat dalam KUHP/WvS merupakan prioritas utama, karena KUHP/WvS merupakan "induk/kodifikasi" dari hukum pidana materiil. Posisi induk ini ada dalam ketentuan Pasal 103 KUHP/WvS, bahwa "Ketentuan dalam Bab I sampai dengan Bab VIII buku ini juga berlaku bagi perbuatan-perbuatan yang oleh ketentuan perundang-undangan yang lain diancam dengan pidana, kecuali jika oleh undang- undang ditentukan lain". Hakikat pembaharuan hukum pidana mengandung makna suatu upaya untuk melakukan orientasi dan reformasi hukum pidana yang sesuai dengan nilai-nilai sentral sosiopolitik, sosio-filosofik dan sosio-kultural masyarakat Indonesia yang melandasi kebijakan sosial, kebijakan kriminal dan kebijakan hukum di Indonesia.

Dengan keberadaan rancangan KUHP nampak jelas adanya nilai-nilai Pancasila dalam ancaman pidana terhadap tindak pidana yang ditentukan. Disamping itu orientasi pemidanaan tidak lagi terfokus pada pelaku kejahatan, akan tetapi sudah berubah paradigma pada korban kejahatan dan masyarakat. Jenis pidana yang dirumuskan dalam rancangan KUHP tersebut tertuang dalam Pasal 65-144 yang masing-masing jenis sanksi ini terdiri dari $:^{21}$

\section{Pasal 65 A}

Pidana terdiri atas:

a. Pidana Pokok

b. Pidana Tambahan; dan

c. pidana yang bersifat khusus untuk tindak pidana tertentu yang ditentukan dalam Undang-Undang ini

\section{Pasal. 66}

1) Pidana pokok sebagaimana dimaksud dalam Pasal 65A huruf a terdiri atas:
a) pidana penjara;
b) pidana tutupan;
c) pidana pengawasan;
d) pidana denda; dan
e) pidana kerja sosial.

2) Urutan pidana sebagaimana dimaksud pada ayat (1) menentukan berat ringannya pidana.

Pasal. 67

(1) Pidana tambahan sebagaimana

$21 \quad$ Aliansi Nasional Reformasi KUHP,Naskah Rancangan Kitab Undang-undang Hukum Pidana(RKUHP)Hasil Pembahasan Panitia Kerja R-KUHP DPR RI (24 februari 2017), Institute For Criminal Justice Reform, http://reformasikuhp.org/data/wpcontent/uploads/2017, diakses tanggal. 17 Mei 2019 
dimaksud dalam Pasal 65A huruf b yang dapat dijatuhkan kepada pembuat terdiri atas:

a) pencabutan hak tertentu;

b) perampasan barang tertentu dan/atau tagihan;

c) pengumuman putusan hakim;

d) pembayaran ganti kerugian;

e) pencabutan surat izin mengemudi; dan

f) pemenuhan kewajiban adat setempat dan/atau kewajiban menurut hukum yang hidup dalam masyarakat.

(2) Pidana tambahan untuk percobaan dan pembantuan adalah sama dengan pidana tambahan untuk tindak pidananya.

(3) Anggota Tentara Nasional Indonesia yang melakukan tindak pidana dapat dikenakan pidana tambahan sebagaimana diatur dalam peraturan perundang -undangan bagi Tentara Nasional Indonesia.

Pasal 69A

Pidana yang bersifat khusus sebagaimana dimaksud dalam Pasal 65A huruf $\mathrm{c}$ adalah pidana mati yang selalu diancamkan secara alternatif

Sementara itu untuk tindakan diatur dalam Pasal 121 Rancangan KUHP.

(4) Setiap Anak dapat dikenakan tindakanberupa:

a. pengembalian kepada orang tua/wali;

b. penyerahan kepada seseorang;

c. perawatan di rumah sakit jiwa;

d. perawatan di Lembaga Penyelenggaraan Kesejahteraan Sosial;

e. kewajiban mengikuti pendidikan formal dan/atau pelatihan yang diadakan oleh pemerintah atau badan swasta;

f.pencabutan surat izin mengemudi; dan/atau

g. perbaikan akibat tindak pidana.

(5) Tindakan sebagaimana dimaksud pada ayat (1) huruf d, huruf e, dan huruf $\mathrm{f}$ dikenakan paling lama 1 (satu) tahun.
Pembangunan sistem hukum nasional yang pada muaranya betujuan mewujudkan kesejahteraan masyarakat dan perlindungan masyarakat, oleh Prolegnas diberi makna sebagai sistem hukum yang menganut asas kenusantaraan yang tetap mengakui keanekaragaman atau heterogenitas hukum seperti hukum adat, hukum Islam, hukum agama lainnya, hukum kontemporer dan hukum barat, serta merumuskan berbagai simpul yang menjadi titik taut fungsional di antara aneka ragam kaidah yang ada melalui unifikasi terhadap hukum-hukum tertentu yang dilakukan, baik secara parsial, maupun dalam bentuk kodifikasi. Dengan demikian pembangunan sistem hukum nasional perlu memperhatikan nilai-nilai hukum yang hidup dalam masyarakat. Perhatian tersebut merupakan hal yang wajar, karena sistem hukum yang saat ini berlaku di Indonesia diantaranya KUHP/WvS disusun berdasarkan nilai-nilai kemasyarakatan yang liberal individual dan tentu berbeda dengan nilai-nilai kemasyarakatan yang religius dan kekeluargaan.

Dari rumusan jenis-jenis pidana yang ditentukan dalam Rancangan KUHP tersebut terlihat jelas perbedaan yang sangat kontras dengan apa yang ditentukan dala KUHP yang berlaku sekarang ini. Dengan harapan pemerintah mempunyai keinginan dalam hal pembaharuan hukum pidana secara umum, sehingga diharapkan mampu menjadi instrumen/sarana preventif dalam pencegahan kejahatan.

\section{Simpulan}

Berdasarkan pada pembahasan diatas dapat disimpulkan bahwa:

1. Penjatuhan Pidana di Indonesia belum memiliki konstelasi dengan nilai-nilai Pancasila, hal ini disebabkan pemidanaan yang dipakai masih merupakan peninggalan kolonial Belanda yang notabennya berlandaskan liberalisme.

2. Penjatuhan pidana dalam sistem pemidanaan di Indonesia dimasa yang akan datang seharusnya berdasarkan 
pada jiwa bangsa Indonesia yang terakomodir dalam nilai-nilai Pancasila yang merupakan falsafah hidup bangsa Indonesia.

3. Sebaiknya pemerintah segera mengesahkan RUU KUHP tersebut menjadi Undang-undang, karena akan sangat berdampak positif dalam penegakan hukum di Indonesia.

\section{DAFTAR PUSTAKA}

Andi Hamzah dan Siti Rahayu, Suatu Tinjauan Ringkas Sistem Pemidanaan Di Indonesia, Akademik Pressindo, Jakarta, 1986

Bernard Arief Sidharta, Paradigma Ilmu Hukum Indonesia Dalam Perspektif Positivis, Universitas Diponegoro, Semarang, 1998

Chairul Huda, Dari Tindak Pidana Tanpa Kesalahan Menuju Kepada Tiada Pertanggungjawaban Pidana Tanpa Kesalahan: Tinjauan Kritis terhadap teori Pemisahan Tindak Pidana dan Pertanggungjawaban Pidana, Kencana Prenada Media, Jakarta, 2006

Ekaputra, Mohammad dan Abul Khair, Sistem Pidana Di Dalam KUHP Dan Pengaturannya Menurut Konsep KUHP Baru, USU Press, Medan, 2010

Kirdi Dipoyudo, Keadilan Sosial. Seri Penghayatan dan Pengamalan Pancasila, Rajawali, Jakarta, 1985
Moeljatno, Azas-azas Hukum Pidana, Bina Aksara, Jakarta,1985

Muladi dan Barda Nawawi Arief, TeoriTeori dan Kebijakan Pidana, Alumni, Bandung, 2005

Mustafa Abdullah dan Ruben Achmad, Intisari Hukum Pidana, Ghalia Indonesia, Jakarta, 1986

R. Soesilo, Kitab Undang-undang Hukum Pidana (KUHP) Serta Komentarkomentarnya Lengkap Pasal Demi Pasal, Politeia, Bogor, 1996

Sajipto Raharjo (editor Awaludin Marwan), Ilmu Hukum Cetakan Ketujuh, Citra Aditya Bakti, Bandung, 2012

Sajipto Raharjo, Paradigma Ilmu Hukum, Alumni, Bandung, 1989

Satochit Kartanegara, Hukum Pidana (Kumpulan Kuliah Bagian I), Balai Lektur Mahasiswa, Tanpa Tahun

S.R. Sianturi, Asas-asas Hukum Pidana di Indonesia dan Penerapannya, Alumni AHAEM-PTHAEM, Jakarta, 1986

Stahl, dalam Abu Daud Busroh dan Abubakar Busro, Asas-Asas Hukum Tata Negara, Ghalia Indonesia, Jakarta, 1982

Teguh Prasetyo, Filsafat, Teori \& Ilmu Hukum (Pemikiran menuju Masyarakat yang berkeadilan dan Bermartabat), PT. Raja Grafindo persada, Jakarta, 2012 